\title{
Academic Library Services: The Literature of Innovation
}

\author{
Judy Reynolds and Jo Bell Whitlatch
}

Innovation has the potential for increasing the effectiveness of information service. As a result of this interest in innovation, organizational theorists have begun to explore the effect of organizational design upon flexibility, creativity, and productivity of organizations. A review of existing literature, however, provides no comprehensive theory of organizational innovation. Research on organizational design and innovation in libraries could contribute to the systematic study of the impact of organizational structure. Studies by Howard and Luquire indicate that traditional library organizations may inhibit change as well as the reexamination of values and service. Further study is needed to determine how libraries can most effectively manage innovation in the rapidly changing environment ahead.

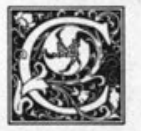

oncern over the future role of libraries is a constant theme in the library literature. The loss of a stable environment, such as declining budgetary support and rapidly changing information technology, has resulted in substantial interest in the planning and evaluation of library services. Libraries have borrowed from business theory and practice in designing, planning, and evaluating programs; but an area in business theory that has received relatively little attention is innovation in organizational design and its influence upon organizational adaptation and survival. Innovation has come into fashion within the last decade. As with all fashionable trends, it is advisable to ask, "Is innovation necessary?" and "Is innovation good?" While it is foolish to argue that all innovation is beneficial, or that continual change for its own sake is desirable, reports in the business literature provide evidence that innovation is often essential for survival. Librarians must read and use the literature of innovation as well as that of planning and evaluation if libraries are to survive in increasingly unstable times. The literature on innovation and organizational design has the potential for assisting libraries in providing effective information services in the rapidly changing environment ahead.

Several interesting studies on organizational innovation have been completed in the past two decades. Although the findings have improved our understanding of innovation, there is not yet a comprehensive theory. Innovation has been difficult to define. Gerald Zaltman's definition is commonly used in studies: "any idea, practice, or material artifact perceived to be new by the relevant unit of adoption."' Other commonly accepted definitions are "the adoption of means or ends that are new to the adopting unit" ${ }^{\prime 2}$ and breaking away from established patterns. ${ }^{3}$

Lawrence Mohr uses Zaltman's definition but specifies that it must be limited to a successful introduction of an idea or practice that has been accepted and implemented by the organization. ${ }^{4}$ Thus he distinguishes between invention (bringing 
something new into being) and innovation (bringing something new into use). Raymond Radosevich suggests that innovation involves major realignments of human, financial, and physical resources of the organization. ${ }^{5}$ This is similar to Jerald Hage's definition of "radical" innovations, which involve high risk and major alterations for the organization and are discontinuous relative to the existing technology. Such radical innovations occur infrequently. ${ }^{6}$ Consequently the focus in this paper will be on low-risk innovation, which is more common in libraries and hence of more concern.

Hage has observed that words such as change, innovation, and creativity are easy to use but not so easy to define or actually observe and measure. ${ }^{7}$ The three principal interrelated working definitions found in the literature are (1) first use, (2) adoption or nonadoption, and (3) extent of implementation. ${ }^{8}$ Moch indicates that studies of the adoption of innovation in organizations have suffered from inadequate definition and from failure to distinguish among types of innovations. Little research has been designed to study differential adoption patterns for various types of organizations. The inconsistent findings that research has produced may be attributed to a failure to take into account the type of innovation and to differences in defining and measuring centralization. . Centralization is the "bringing together of operations or functions of similar types into a common grouping." The resulting administrative design is a "system in which authority for directions, control, and management has become concentrated in the hands of a few persons or offices." $" 10$

Chris Argyris notes five common types of innovation: (1) products, (2) processes, (3) tasks, (4) persons, and (5) environmental variables. ${ }^{11}$ Zaltman has a slightly different list: (1) product or services, (2) production process, (3) organizational structure, (4) people innovations, and (5) policy innovations. ${ }^{12}$ Richard Daft divides innovations into those occurring in the operations area, where the basic production of services or products takes place, and those in the administrative area. ${ }^{13}$ Organi- zational and environmental variables may be associated with activity in one area but not the other. ${ }^{14}$

This paper focuses on the effects of organizational structure upon innovations in both the technical operations and the administrative areas of the organization. Zaltman suggests that the essential variable determining how organizations react to their external environment is organizational structure. ${ }^{15}$ Daniel Katz and Robert $\mathrm{Kahn}$ also indicate that the direct manipulation of the various components of organizational structure is a powerful means of producing systematic change. ${ }^{16}$ Jerald Hage and Michael Aiken indicate that the structure of an organization may be more crucial for the successful implementation of change than the particular blend of personality types in the work place. ${ }^{17}$

An organization can be defined as an adaptive system that must continually improve its performance to stay alive in modern society. ${ }^{18}$ Even the cumulative effects of minor change can be important in ensuring organizational survival. Most relevant to the study of innovation in libraries is Mohr's definition of innovation-the successful introduction into an applied situation of means or ends that are new to that situation.

\section{THEORIES OF INNOVATION}

The theories of innovation presented in this section are based upon data gathered from the study of organizations. A summary of the major studies is provided in table 1; details of the experimental studies are also provided in the references cited in this paper. There is also an extensive literature that deals with innovation and organizational climate but does not focus primarily on organizational design. This aspect of innovation is outside the scope of this paper.

One of the earliest theories of innovation was proposed by James March and Herbert Simon. Innovations occur when a given program of activity no longer satisfies performance criteria. ${ }^{19}$ Dissatisfaction stimulates the organization's search for alternative courses of action. ${ }^{20}$ Research indicates that the highest job satisfaction is not correlated with the highest innovation 
TABLE 1

MAJOR STUDIES OF INNOVATION AND ORGANIZATIONAL STRUCTURE

\begin{tabular}{|c|c|}
\hline Author and Date Published & Major Conclusions \\
\hline $\begin{array}{l}\text { Burns and Stalker, } \\
1961\end{array}$ & $\begin{array}{l}\text { The environment heavily influences organizational adoption of mechanistic } \\
\text { or organic management techniques. }\end{array}$ \\
\hline $\begin{array}{l}\text { Hage and Aiken, } \\
1970\end{array}$ & $\begin{array}{l}\text { The higher the organizational characteristics, such as complexity, } \\
\text { centralization, formalization, and stratification, the lower the rate of } \\
\text { innovation in organizations. }\end{array}$ \\
\hline $\begin{array}{l}\text { Zaltman, Duncan, } \\
\text { and Holbek, } 1973\end{array}$ & $\begin{array}{l}\text { Complexity facilitates innovation in the initiation stage, while higher } \\
\text { formalization and centralization and lower complexity facilitate the adoption } \\
\text { of innovation. }\end{array}$ \\
\hline $\begin{array}{l}\text { Hage and Dewar, } \\
1973\end{array}$ & $\begin{array}{l}\text { Values of the organizational elite are more effective in predicting rates of } \\
\text { program innovation than structural variables. }\end{array}$ \\
\hline Mintzberg, 1983 & $\begin{array}{l}\text { Changes in professional training and norms lead to organizational } \\
\text { innovation. }\end{array}$ \\
\hline Howard, 1977 & $\begin{array}{l}\text { Findings generally support Hage and Aiken except in the area of complexity. } \\
\text { Librarians' professional training was positively correlated with innovation, } \\
\text { but the correlation with participation in professional organizations was } \\
\text { negative. }\end{array}$ \\
\hline Luquire, 1983 & $\begin{array}{l}\text { Organizational size was negatively associated with acceptance of innovation, } \\
\text { but positively associated with professional training. }\end{array}$ \\
\hline
\end{tabular}

phase of an individual's career. Contentment with performance does not appear to induce innovation; instead, dissatisfaction with the "performance gap" is the catalyst to change. A moderate gap between what individuals desire and what they are presently able to achieve may be necessary to create the energy required for change and accomplishment. ${ }^{2}$

According to Michael Moch and Edward Morse, there is an identifiable cluster of characteristics that determine an organization's proclivity for adopting new techniques. ${ }^{2 \mathrm{P}}$ In the theory developed by Tom Burns and G. M. Stalker, the environment has an important influence on whether firms adopt more organic management techniques. An organic structure is characterized by loose, informal relationships built upon mutual adjustment and the absence of standardization. The organization responds to its environment and adapts to changes in order to survive. While there is no one best model for organizing, a mechanistic form is more suitable when the environment is stable and fairly certain. A mechanistic organization operates like a machine and can only be stopped or broken. When the technical and market environment is changing and unstable, organic forms have an advan- tage due to their increased potential for gathering and processing information. ${ }^{23}$ Burns and Stalker note that when organizational outputs are services rather than manufactured products, the organization is apt to show more adaptiveness because there is reduced ability to standardize tasks. ${ }^{24}$ Aiken and Hage have found empirical support for the notion that the organic organization has characteristics that facilitate innovation. ${ }^{25}$

Aiken and Hage have developed a major theory relating innovation to organizational structure. They have identified several organizational characteristicsincluding complexity, centralization, formalization, and stratification-that affect the rate of innovation in organizations. They hypothesize that the higher the formalization, stratification, volume of production, centralization, and emphasis on efficiency, the lower the rate of innovation. Innovative organizations also have more elaborate committee structures than noninnovative organizations. ${ }^{26}$ Central to their theory are propositions drawn from the writings of Max Weber's model of bureaucracy, Chester Barnard's stratification, and Victor Thompson's growth of occupational specialties. ${ }^{27}$ Hage and Aiken suggest that increased formaliza- 
tion and higher degrees of job codification in an organization decrease the rate of innovation. However another study disputes their conclusions and proposes that it may be job autonomy rather than job codification that is associated with new programs. The scales for job codification, designed to observe and measure formalization, may not be measuring that specific construct. $^{28}$

Using educational organizations as an example, Karl Weick has argued that the prevailing image of organizations operating through dense, tight linkages such as planning mechanisms is probably false. Educational organizations might be better described as loosely coupled systems. This characteristic of educational systems could promote more sensitivity to the environment and localized adaptation. ${ }^{29}$ Burton Clark suggests that the basic direction of change in the bottom-level operating units of the university is toward fragmentation and loose coupling. He indicates that the fundamental adaptive mechanism of universities and larger adaptive systems is the capacity to add and subtract some fields of knowledge and related units without much disturbance to others. The sources of change are the interests, ideas, and organization of each of these areas. ${ }^{30}$ The diversity and fragmentation of the units creates intense competition for scarce resources.

The Zaltman theory treats innovation as a process and distinguishes between the initiation and implementation stages. A five-stage model of innovation is presented. The two major stages are (1) initiation and (2) implementation. The initiation stage is further segmented into three divisions, knowledge-awareness, formation of attitudes, and decision. The implementation stage is segmented into two divisions, initial implementation and continued-sustained implementation. Zaltman suggests that complexity of the organization may have both positive and negative effects upon innovation: positive in the more loosely structured proposal stage but negative in the more tightly structured implementation stage. ${ }^{31}$ The organizational characteristics facilitating innovation in the initiation stage are more complex but less formal and centralized. However, at the implementation stage organizational characteristics facilitating adoption are lower in complexity, but higher in formalization and centralization. ${ }^{32}$

Since the development of the original theory by Aiken and Hage, Hage and Robert Dewar have found that none of the structural variables (complexity, centralization, formalization) is as effective as the values of the elite inner circle of executives in predicting differential rates of program innovation. ${ }^{33}$ The elite inner circle is composed of the executive director and those managers who participate in strategic decisions about policies, programs, personnel, and promotions. Hage and Dewar find that the values of the elite inner circle are more influential than those of only the chief executive or of the entire staff, particularly if one uses a behavioral rather than a formal definition of elite values. ${ }^{34}$ Hage observes that centralization generally will be positively related to innovation rate if the values of the dominant coalition (those participating in strategic decision making) are pro-change. ${ }^{35}$ Argyris also studied the influence of top management upon organizational innovation and found the dominant coalition to be influential. He concludes that management with weak interpersonal skills will cause deterioration of innovation in the organization. ${ }^{36}$

Henry Mintzberg's work on organizational structures is also of interest. Mintzberg defines innovation as breaking away from established patterns. Thus, the truly innovative organization cannot rely on any form of standardization for coordination. It must avoid all the trappings of bureaucratic structure, notably the sharp divisions of labor, extensive unit differentiation, highly formalized behav iors, and emphasis on planning and cor trol systems. ${ }^{37}$ However, Mintzberg i. talking about radical innovation. He does observe that existing programs can be perfected and standardized by specialists, but new ones usually cut across existing specialty boundaries. ${ }^{38}$ Mintzberg calls one organizational structure the "professional 
bureaucracy." The organization allows for both standardization and decentralization. Coordination is provided by employees sharing a standard set of skills and knowledge that transcends organizational boundaries. The professionals use their skills in response to predetermined service categories. Clients are categorized in terms of the functional specialties the library offers. ${ }^{39}$ Change in the professional bureaucracy occurs through altering of the type of people who enter the profession, their norms, skills, and knowledge acquired in professional schools and in subsequent continuing education. ${ }^{40}$

Other researchers have also found professional contacts to be important. Daft reported positive associations between professionalism and innovation in the technical area. ${ }^{41}$ Professionalism can also have some negative effects upon innovation. Mayer Zald and Patricia Denton identify predictors of innovation as the breadth of organizational goals and the absence of a single dominating professional ideology. ${ }^{42}$ Aiken and Hage found that it is the current degree of involvement of staff members in extraorganizational professional activities, not the initial level of professional training, that is most highly related to successful implementation of innovation. ${ }^{43}$ In confirmation of this research, Katz found that isolation from sources providing evaluation, information, and new ideas is the most critical factor resulting in ineffective project performance. ${ }^{44}$ James Utterback's work also indicates that the primary limitation on an organization's effectiveness in innovation is neither costs nor technical knowledge, but the ability to recognize the needs and demands in its external environment. ${ }^{45}$

For Zaltman, the organization is an open system in continued interaction with its environment. The organization must determine which products or services will be most readily received by the end users and focus innovative efforts in those areas. The organization must also adapt its technology to produce these new products or services and monitor the environment for feedback to determine if the innovation is effective in meeting the demands of the environment. ${ }^{46}$
Hage and other theorists have concluded that innovation and efficiency are negatively related and appear to require opposing types of organizational structures. Efficiency is usually positively associated with centralization and formalization, and may be either positively or negatively associated with complexity. Yet organizations must be both efficient and innovative to survive in a changing world. ${ }^{47}$ Jon Pierce and Andre Delbecq suggest that the solution to this paradox probably lies in capital venture systems, matrix systems for initiating and varying the organizational design using project groups in the initiation stages and structured decision bodies in the implementation stages. ${ }^{48}$ The matrix system provides a dual focus when more than one orientation is critical for managing the organization.

An organizational structure, which Mintzberg terms the "adhocracy," uses the functional and market bases for grouping in a matrix structure. The experts are grouped into functional units for normal purposes, but are deployed into project teams for the purpose of encouraging innovation. ${ }^{49}$ Mintzberg observes that even hospitals and universities, which are closest to the "professional bureaucracy" for their routine clerical and teaching work, are drawn to the "adhocracy" when they attempt truly innovative work. Specialists must join together in multidisciplinary teams to create new knowledge and skills. ${ }^{50}$ Figures 1, 2, and 3 illustrate the theoretical difference between typical hierarchical and less traditional structures in libraries.

\section{ORGANIZATIONAL STRUCTURE AND INNOVATION IN LIBRARIES}

Certainly innovation in itself is intrinsically neither good nor bad. Multiple views have been expressed on the value of a recent innovation in librarianship, the adoption of AACR2. Another innovation in library services, networking or resource sharing, also has both positive and negative attributes. Networking can increase access to resources but may result in the loss of local library autonomy in setting 


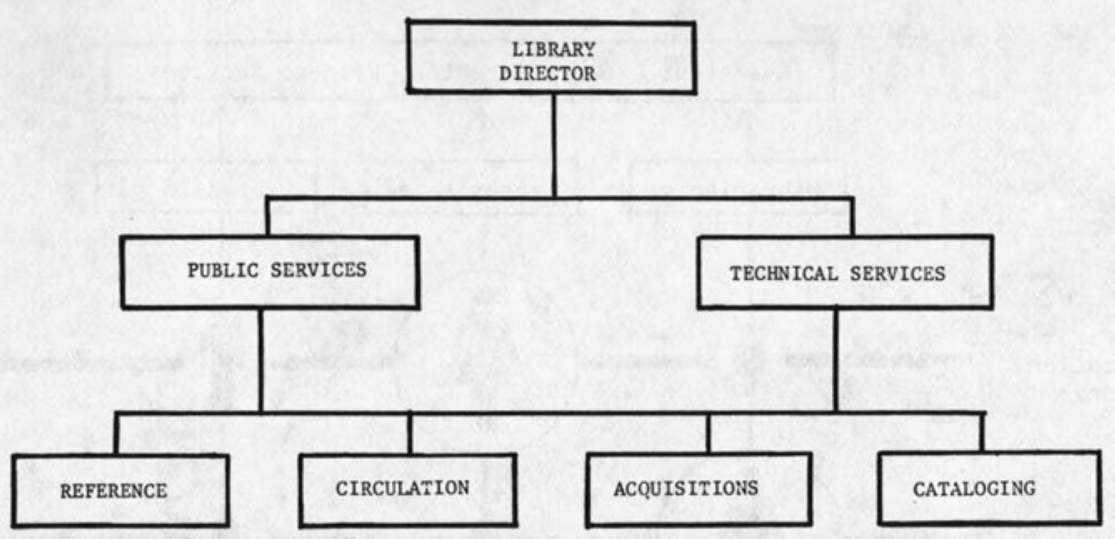

FIGURE 1

Example of Traditional Hierarchical Structure

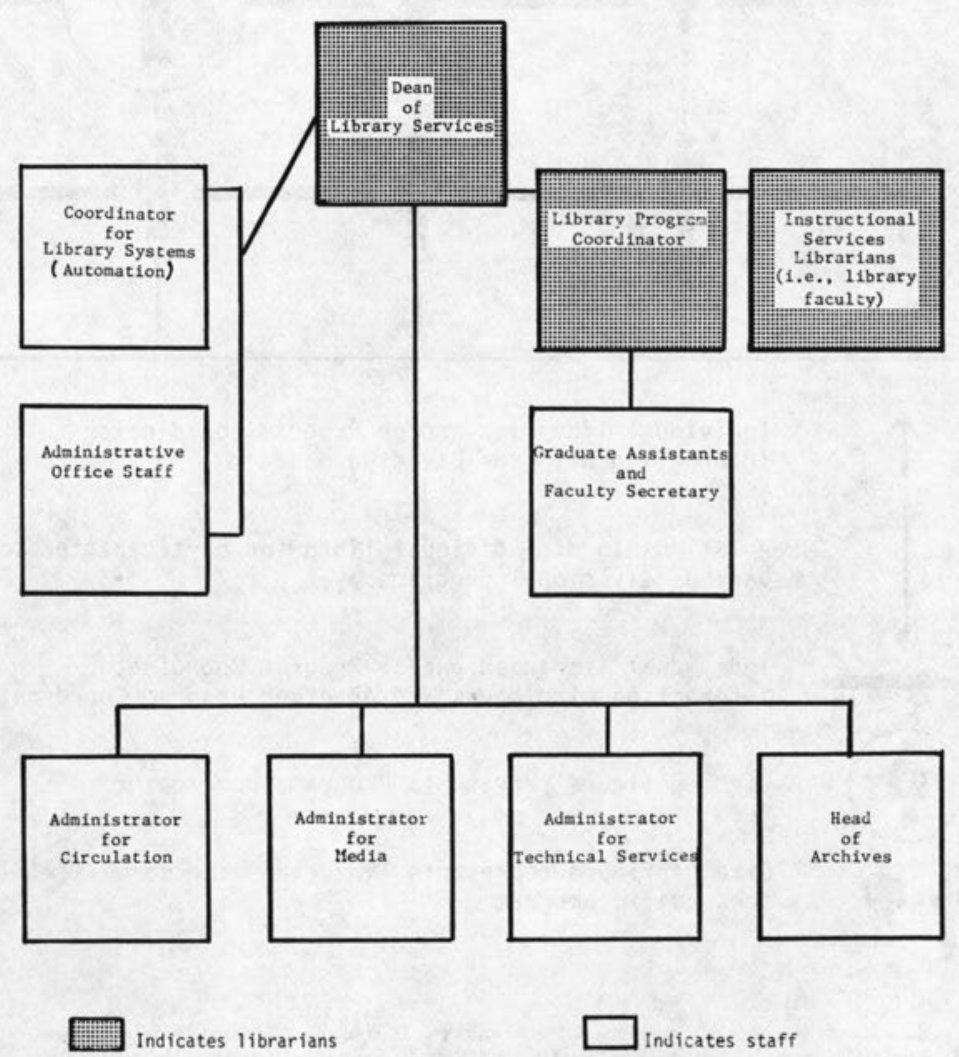

Adapted from Patricia Senn Brevik, "A Model for Library Management," Personnel in Libraries: LJ Special Report "10 (New York: Bowker, n.d.), p.9.

FIGURE 2

Sangamon State University Library Organizational Chart (April 1978) 

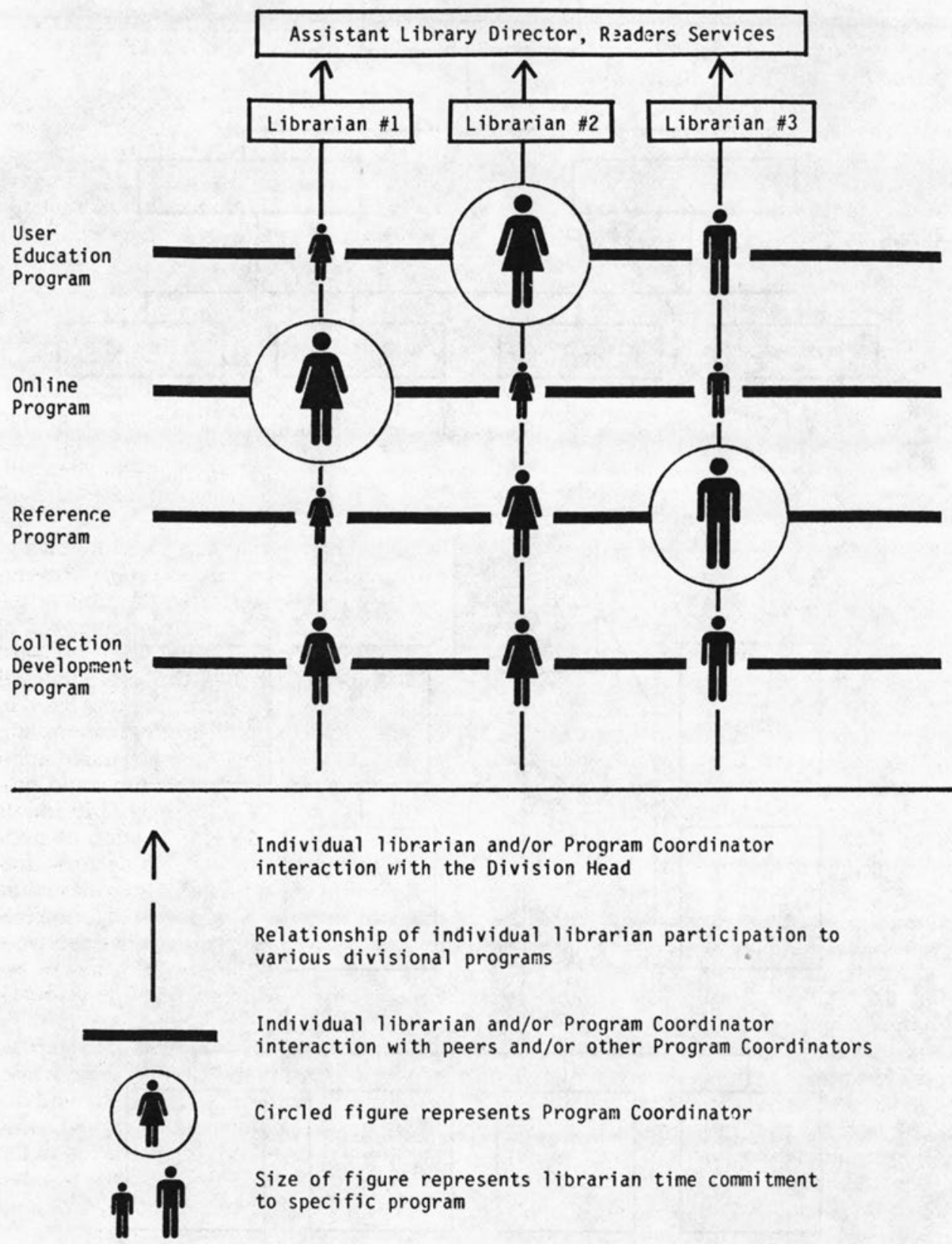

Reprinted, by permission of the authors, from Joanne R. Euster and Peter D. Haikalis, "A Matrix Model of Organization for a University Library Public Services Division," in Academic Libraries; Myths and Realities, Proceedings of the Third National Conference of the Association of College and Research Libraries (Chicago: ACRL, 1984), p.362.

\section{FIGURE 3}

A Schematic of Matrix Organization for the Reader Services Division of San Francisco State University 
budgets, service priorities, and collection development policies. Bibliographic instruction and online database searching have also extended library services and enriched the interaction between the library and its environment. Some argue that provision of these new services reduces the resources available for the more traditional library services. Nonetheless, change is inevitable and the library that plans and encourages creativity is most likely to cope effectively.

Much of the literature on innovation in libraries is a call for its exercise and/or listings of possible areas of need or application. Connie Dunlap suggests that collegial or participatory staff organizations will increase staff interest in library-wide concerns resulting in greater productivity and adaptability. The more prevalent "bureaucratic organizations tend to produce conformity and generally stifle creativity. ${ }^{51}$ Victor Thompson states that a "well managed" organization "tends to define jobs and jurisdictions which lack variety and richness of cognitive inputs usually associated with creativity. The creative process is characterized by slowness of commitment, by suspended judgement, by refusal to grasp the opportunity and make quick decisions." He surmises that "it is very difficult for the person cataloging all day to be creative." 52

As a public service organization, the library must constantly review its goals as an "open system" that is responsive to the public. Peter Drucker defines the public as: (1) "the people who depend on you," the library users, and (2) "any group that can in effect stymie you. ${ }^{, 153}$ In the latter case he suggests that modifying services to satisfy the patron will be difficult because staff may not wish to abandon established services in favor of new ones. He wagers, "that your really effective resources, both human and money, will be invested in defense of yesterday. " ${ }^{54}$ Harvey Kolodny cautions against the apparent closed system that libraries have provided to the public. Management "must stop functioning like librarians that are waiting for people to come to them because they control the source of a particular skill or knowledge or discipline . . ."

\section{DISCUSSIONS OF INNOVATION IN LIBRARY LITERATURE}

Automation, budget crises, increasingly sophisticated patron needs, complex copyright regulations, resource sharing, and demands for professional autonomy are factors leading to a flurry of demands in library literature for change, creativity, and innovation in libraries. ${ }^{56}$ Mary Lee Bundy advocates the release of " powerful growth forces" to counteract tendencies toward conformity and restriction of service modifications. She proposes restructuring the organization into two areas: one would operate collegially in discipline units providing selection, indexing, and reference; the second area would be auxiliary services, governed by committees of professionals who would set policy for the purchasing, processing, and inventory units composed of support staff. ${ }^{57}$ This arrangement is similar to the innovative structure successfully implemented at Sangamon State University. ${ }^{58}$ Howard Dillon has described this experimental new organizational structure that freed librarians from administrative responsibilities. ${ }^{59}$ Patricia Brevik later expanded upon the design. Bundy's structure could provide responsible units and individuals with increased decentralization of decision making. It would also decrease formalization of professional activities while maintaining the high degree of formalization already present in auxiliary services and increasing the stratification of rewards between support staff and librarians.

Bundy proposes that support staff be compensated equitably for their work. The positive effects of collegiality and decentralized decision making upon the rate of innovation, which are predicted in the Hage and Aiken model, might be negated by excessive formalization, rigidity, and stratification in auxiliary services.

Robert Moran accuses academic libraries of maintaining an organizational design that "addresses only internal matters," hindering their response to the environment. He proposes an "outside surveillance" unit, specifically collection development, which would be decentral- 
ized and informal. An advisory group of librarians would be formed to provide the director with insights gained from participation in external professional associations. The director would assume responsibility for attending to external matters as well as internal needs. Moran states that this modified bureaucratic model would offer a more responsive, open system. ${ }^{60}$ The organizational changes proposed by Moran are supported by Hage and Aiken's theory, which predicts that decentralization and informality will increase the rate of innovation.

Karl Musmann observes that libraries have the same problems with structure and innovation that Mintzberg outlined. As agencies that are externally controlled for the most part, their structure is highly formalized, bureaucratic, and centralized. Musmann says this is "not conducive to successful survival in a dynamic environment nor is it especially suited to encourage innovative behavior. ${ }^{\prime \prime 1}$

The Booz, Allen, and Hamilton study of Columbia University in 1970-71 advocated restructuring the organizational design so that the library would be better able to function as an open system and effectively respond to the changing needs of the academic community. ${ }^{62}$ Lowell Martin believes that libraries should consider Peter Drucker's basis of organization. Drucker states that organizational structure should flow from purpose and that the proper structure cannot be determined until the organization's objectives are clarified. According to Martin, applying Drucker's organizational ideas to a university library structure could result in two primary divisions: the instructional division and the graduate or research division. This structure would shift the organizational emphasis from the traditional functions, such as acquisitions, cataloging, reference, and circulation, to a focus on the library's purpose and users. ${ }^{63}$ Academic library structures based upon undergraduate libraries and graduate research branches appear to incorporate the basic concepts embodied in Martin's twodivisional design.

Another redesign suggestion comes from Gardner Hanks and James Schmidt, who feel that the professional model is deficient because it discourages change. They argue that it encourages members to defend a stereotype of acceptable client needs and professional responses, creating, in effect, a closed system. ${ }^{64}$ They recommend the replacement of the traditional functional organization with one based on the types of clients served. They do not consider the possibility of a matrix structure with attention given to both special services to clients and the need to maintain efficiency in the delivery of standard library services. Their recommendation is supported by Mintzberg's model of the professional bureaucracy and Hage and Aiken's predictions that formalization reduces the search for better methods of doing work. ${ }^{65}$ Hanks and Schmidt note that more emphasis in library schools on theoretical and applied sciences would help solve the problem by introducing to librarians an understanding of open systems. Librarians might then demand less formal, more responsive libraries. Joseph McDonald also observes that professionalism is a problem. He notes that organizational design, i.e., the division into functions such as reference librarian, archivist, and bibliographer, "dictates how the user must approach the organization for service and how the service is offered to him. ${ }^{\prime \prime 66}$ In the professional bureaucracy, the division of work into narrow specialized functions severely inhibits innovation and often creates difficulty in resolving routine matters requiring communication and cooperation between personnel in different functions. McDonald indicates that organizational design may be a key element in successful library services, but points to the problems of defining and measuring library effectiveness. Miriam Drake and Harold Olsen state that "innovation does not happen by chance. ${ }^{\prime 67}$ It is a response to the external environment or an attempt to increase effectiveness. Fiscal pressures will force libraries into "increased reliance on consumer self-service as a primary mode of operation.'

Helen Howard cites several doctoral dissertations, all of which found few differences in formal academic library structures. ${ }^{68}$ The focus on investment of human 
resources in bibliographic organization and the utilization of performance measures appropriate to a closed system have constrained libraries from adopting new, more user-oriented organizational designs. ${ }^{69}$

Charles Martell recommends an alternative to the traditional functional design that brings librarians together into small work groups allied with designated client groups in the academic community. Librarians would perform multiple functions within these units: advanced reference, collection development, online searching, and original cataloging. He indicates that this design bears some resemblance to the Booz, Allen, and Hamilton's design at Columbia but has greater emphasis on client needs. ${ }^{70}$ Support for Martell's design can be found in current popular works such as Corporate Cultures by Terrence Deal and Allan Kennedy and In Search of Excellence by Thomas Peters and Robert Waterman.

Deal and Kennedy predict that managers of the future will structure and negotiate appropriate economic arrangements with workers banded together into semiautonomous units. Freedom and autonomy will be gained when telecommunications networks and systems exist to provide many of the communication links now requiring coordination of people in large organizations. Culture will become the bond that holds these units together. ${ }^{71}$ This structure may also be more conductive to innovation.

In observing excellent companies, Peters and Waterman note that these companies are "better listeners." They pay attention to their lead users, and most of their innovations come from the marketplace. ${ }^{72}$ Peters and Waterman also question the value of the matrix structure and note that it almost always ceases to be innovative after a short time. They suggest that the product division is probably still the best form around for providing the simple structural form and lean staffing so necessary for organizational flexibility at the corporate level. They note that this simple structural form can be reorganized around the edges, e.g., by creating experimental units. There is evidence that large library organizations do not facilitate the adoption of new technology. Musmann found evidence that the large size, complexity, and decentralization of power within the California State University and Colleges System contributed to an environment of slow decision making. ${ }^{73}$

Thomas Shaughnessy warns that decentralization can deteriorate into an overemphasis on specialization at the expense of overall organizational needs. Organizational redesign can be used to maintain the balance between specialization and attainment of overall goals. "Coordination by plan" is a mechanistic response, effective in stable situations where units have standard tasks, policies, and interactions. "Coordination by feedback" is an organic response to dynamic, changing situations. Shaughnessy sees the latter as becoming more prevalent through the employment of such devices as coordinator positions. ${ }^{74}$ Citing Alan Dyson's study of library instruction programs, Shaughnessy recommends increased support for coordinator positions in order to make the library a more open system. ${ }^{75}$ Theoretical support for such a structure is provided by the Hage and Aiken model, which would predict an increase in innovation by decreasing centralization, formalization, and stratification.

Textbooks on library management usually have not addressed the design of an organization as anything but a given. The library organization is consistently divided into public and technical services and is hierarchical. One exception is John Rizzo's text, which makes no attempt to review the literature of library management. Instead, Rizzo reviews the larger world of management theory and research for librarians, who are expected to make their own judgments on applicability. While the work devotes most of its attention to group dynamics and techniques, it does touch lightly upon aspects of organizational design as characteristics to be manipulated rather than accepted as permanent fixtures. Division of labor, task design, job enrichment, formality, centralization, organizational development, project teams, matrices and committees, the need to tolerate ambiguity, and equita- 
ble representation are mentioned. The work of Burns and Stalker is noted: "their data show that organizations that cling to the formalized hierarchy when their environment becomes dynamic do poorly in the marketplace." Those that shift to more organic forms tend to prosper. ${ }^{76}$ Rizzo recommends further reading in this area, but provides no model or review of the limited research that has been done.

\section{RESEARCH IN LIBRARIES}

Helen Howard has done the most extensive research on the effects of organizational structure in libraries. ${ }^{77}$ She tested Hage and Aiken's hypothesis in four academic libraries. Unfortunately, the study results may not be generalizable beyond these four libraries. Nonetheless, Hage and Aiken's model was successfully applied, and Howard encourages other researchers to replicate the study to verify her findings. She defined innovation broadly as "the generation, acceptance and implementation of new ideas, processes, products or services for the first time within an organization. ${ }^{\prime 78}$ Howard found that the data largely supported Hage and Aiken's hypothesis that innovation would be negatively related to the degree of centralization, formalization, and stratification, and positively related to complexity. In other areas Howard's findings differed from Hage and Aiken's. In their study of health and welfare agency workers, occupational specialization and professional activities were the two indexes of complexity most positively related to innovation. Professional training had a negative relationship. In her study of librarians, Howard found innovation to be more strongly correlated with professional training (total subject and professional degrees earned). Howard's findings should be replicated since they do not support McDonald's or Hanks and Schmidt's beliefs that professional training serves as an obstacle to innovation.

Specialization and professional activities were only weakly associated with innovation. Howard suggests this may be because librarians have been conditioned to think of themselves as generalists. While librarians may possess such specific titles as "selector," "'head of map room," or "East Asian bibliographer," these titles may not reflect much more than vague organizational structures and fuzzy roles. A librarian's job title may not signify the clear distinction between occupational specialties found in another industry employing a wide diversity of skilled personnel with various professional degrees. The weak correlation between professional activities and innovation may indicate that the quality of professional activities needs to be strengthened in order to contribute to innovation as they do in the health and welfare professions.

In systems of higher education, Clark observes that change promoted by external influence comes about in largely unnoticed ways through boundary roles at the bottom level of the academic system. Professors engage in activities characteristic of boundary roles, such as information gatekeeping, transacting with other groups, and linking and coordinating with the inside and outside. ${ }^{79}$ Charles Bunge reports that two-thirds of the reference librarians in thirty-five libraries he surveyed relied on conferences and workshops to update their knowledge and skills. ${ }^{80}$ Howard's study raises an important question: Are professional associations living up to their potential as catalysts for innovation?

Participation in decision making was another strong indicator of innovation in libraries. This supports Hage and Aiken's hypothesis that decentralization encourages innovation. The scales used in developing the measures of centralization and formalization have recently been criticized by Robert Dewar, David Whetten and David Boje. ${ }^{81}$ Further testing of the instrument is recommended before use in another study.

Howard reports that 31 percent of the innovations were in organizational structure (reorganizations of major portions of a library); 25 percent in the production process (e.g., adoption of OCLC); 25 percent in people, (e.g., appointment of new occupational specialists, staff development); and 19 percent in products and services. Howard states that the "reorganization total (31 percent) supports the 
literature, which gives the impression that all organizations are in a frenzy of reorganization whether they need it or not. ${ }^{\prime 82}$ This observation also coincides with Drucker's view that reorganization is often used as a substitute for getting at the real cause of problems, especially personnel problems.

Maurice Marchant measured patron, faculty, and staff evaluations of academic libraries as an end product of an open system. His findings suggest that participatory management ultimately results in faculty and staff perceptions of better service. ${ }^{83}$ Further investigation is warranted to determine if the correlation Howard found between innovation and participation does indeed produce improved or more effective services. One should keep in mind Jane Flener's observation that in most libraries less than 50 percent of the staff seemed interested in participating in management. ${ }^{84}$

Beverly Lynch concludes that the technology of library work, as defined by employee perceptions, appears to vary in degree of difficulty or sophistication fairly uniformly across different libraries. She defines technology as "the actions that an individual performs on an object, with or without the aid of tools or mechanical devices, in order to make some change in that object" and bases her study on measures of technology developed by Charles Perrow. ${ }^{85}$ Lynch found that professional work, as defined by functional departments such as reference and cataloging, appears to be at a higher level than those that are largely support staff functions such as acquisitions and circulation. This measure should be verified against a careful analysis of skill, effort, and responsibility, such as that done at the San Jose Public Library. ${ }^{86}$ Research results could be compared with Howard's work to see if variations in the highly centralized, formalized, and stratified institutions, such as those Lynch studied, demonstrate increased innovation when the organizational structure is redesigned into a less traditional form.

Wilson Luquire provides us with a study of technical services librarians' perceptions of an innovative system, OCLC.
He finds that acceptance of the innovation correlates positively with participation in decision making, variety and interest in the work, professional training, and amount of preparation for the system. Luquire's results support the predictions of Hage and Aiken: organizational size correlates negatively with acceptance, which corresponds favorably with the hypothesis that centralization will have negative effects. However, larger libraries are more likely to have problems with the introduction of shared cataloging systems, as they are more frequently the contributors than the benefactors, and may have a greater need for higher levels of cataloging that will distinguish between editions.

\section{FUTURE RESEARCH NEEDS}

Only limited study has been made of relationships between organizational design and innovation in libraries. The present accounts in the literature on the positive effects of adopting a collegial management structure are limited in application. Based upon her experience at a small library, Dickinson College in Carlisle, Pennsylvania, Joan Bechtel says, "the creativity and flexibility generated by our new library organization have yielded maximum results in efficiency and staff satisfaction. ${ }^{188}$ Research is needed to verify her assertions and determine if this system will function in a library with more than seven librarians.

Many questions remain to be investigated. Louis Kaplan suggests several questions for study. For example, can top management "surrender its policymaking responsibility in a heteronomous, service-type agency?", 89 Is it the situation or the manager that is participative or autocratic? To what extent will employees be willing to assume responsibility in a shared authority system? And when and why do managers use decision sharing $?^{90}$

One of the greatest barriers to the investigation of organizational design in libraries is that it is difficult to measure effectiveness. If innovation is desirable, it should be beneficial and in some proportion to its cost. Rosemary DuMont proposes an open systems approach that focuses on process rather than product. A 
library will be effective, she suggests, if (1) the employees affirm its goals; (2) it responds to environmental changes; (3) it provides timely, relevant and accessible services; and (4) it monitors user needs. ${ }^{91}$

What has been investigated so far and what do we know? Additional research based on organizational behavior theories and models would permit us to judge whether the results of innovation theories and studies of business firms can be generalized to libraries. More study needs to be done to determine the effects of centralization, complexity, formalization, and stratification upon innovation. These studies need to compare libraries of various types, sizes, and levels of wealth, private and public institutions, and those with common and divergent goals. These organizational variables must be measured against the different types of innovation characteristics: cost, time required, impact on work group, administration, and users, compatibility with organization and employee goals, technicality, and payoff. Although Howard and Luquire have measured some of the organizational variables, no study has been done measuring the different characteristics of innovation. And these studies are a "snapshot in time," as it were, and do not purport to investigate the process of innovation: the initiation, introduction, adoption, and diffusion. Does the same innovation take on various hues when viewed from different employee points of view? How will resource sharing affect innovation when institutional boundaries are transcended? How does one define success or effectiveness, and is it the same across institutions?

\section{CONCLUSION}

There is no comprehensive theory of organizational innovation to provide significant insight beyond the boundaries of our own field. Library research could contribute to the systematic study of organiza- tions and provide information on innovation and organizational design. It is imperative that libraries take the initiative in times of limited funding. Richard Dougherty warns, "If innovation activities are sacrificed in order to preserve existing activities, librarians will eventually force their organizations into operational straightjackets." ${ }^{\prime 92}$ The operational straightjackets provide a closed system for libraries which could be devastating to their survival as organizations. Hage recounts an instance when Burgess at Columbia attempted to get the library to order new books for his courses and to be open for more than two hours a day. When the librarian refused to support his attempts to introduce innovative new courses, Burgess went to the Board of Regents and obtained permission to start an entirely new library.

Recognition of the need for innovation is becoming more widespread. Carlos Cuadra provides an excellent summary of the need for librarians to understand and investigate how library organizations can encourage innovation:

It is in no way necessary or inevitable that librarians shift the balance of their holdings and services to include microforms, digital information, videotapes, holograms and other trappings of advanced technology. It is not necessary that libraries shift their concept of operations from circulation to outright distribution. It is not necessary that libraries invest in computers and other paraphernalia to provide users with a higher order of access to reference materials. It is not necessary that libraries become elements of networks for the raised identification and provision of materials to users, regardless of geographical location.

However these functions are going to take place and if the library does not bring them about, some other type of agency will. That agency will then occupy the central role in the information business-the role that was once occupied by the library. ${ }^{94}$

\section{REFERENCES}

1. Gerald Zaltman, Robert Duncan and Jonny Holbek, Innovations and Organizations (New York: Wiley, 1973), p.10.

2. George W. Downs, Jr., "Conceptual Issues in the Study of Innovation," Administrative Science Quarterly 21:701 (Dec. 1976). 
3. Henry Mintzberg, Structure in Fives: Designing Effective Organizations (Englewood Cliffs, N.J.: Prentice-Hall, 1983), p.254.

4. Lawrence B. Mohr, "Determinants of Innovation in Organizations," American Political Science Review 63:112 (Mar. 1969).

5. Raymond Radosevich, "Designing Innovative Systems," Long Range Planning 10:80 (Apr. 1977).

6. Jerald Hage, Theories of Organizations (New York: Wiley, 1980), p.188.

7. Ibid., p.165.

8. Downs, "Conceptual Issues in the Study of Innovation," p.709.

9. Michael K. Moch and Edward V. Morse, "Size, Centralization and Organizational Adoption of Innovations," American Sociological Review 42:716 (Oct. 1977).

10. Jerry Martin Rosenberg, Dictionary of Business and Management, 2d ed. (New York: Wiley, 1983), p.90.

11. Chris Argyris, Organization and Innovation (Homewood, Ill.: Irwin, 1965), p.2.

12. Zaltman, Innovations and Organizations, p.14-15.

13. Richard L. Daft, "A Dual-Core Model of Organizational Innovation," Academy of Management Journal 21:206 (June 1978).

14. Ibid., p.209.

15. Zaltman, Innovations and Organizations, p.121.

16. Daniel Katz and Robert L. Kahn, The Social Psychology of Organizations, 2d ed. (New York: Wiley, 1978), p.711.

17. Jerald Hage and Michael Aiken, Social Change in Complex Organizations (New York: Random, 1970), p.122-23.

18. Kenneth E. Knight, "A Descriptive Model of the Intra-Firm Innovation Process," Journal of Business 40:483 (Oct. 1967).

19. James March and Herbert Simon, Organizations (New York: Wiley, 1958), p.182.

20. Ibid., p.174.

21. Ralph Katz, "High Performance Research Teams," Wharton Magazine 6:31 (Spring 1982).

22. Moch, "Size, Centralization and Organizational Adoption of Innovations," p.723.

23. Tom Burns and G. M. Stalker, The Management of Innovation (London: Tavistock, 1961).

24. Ibid.

25. Michael Aiken and Jerald Hage, "The Organic Organization and Innovation," American Journal of Sociology 5:79 (Jan. 1971).

26. Ibid., p.75.

27. Jerald Hage, "An Axiomatic Theory of Organizations," Administrative Science Quarterly 10:296 (Dec. 1965).

28. Robert D. Dewar, David A. Whetten, and David Boje, "An Examination of the Reliability and Validity of the Aiken and Hage Scales of Centralization, Formalization and Task Routineness," Administrative Science Quarterly 25:127 (Mar. 1980).

29. Karl E. Weick, "Educational Organizations as Loosely Coupled Systems," Administrative Science Quarterly 21:1-19 (Mar. 1976).

30. Burton R. Clark, "The Contradictions of Change in Academic Systems," Higher Education 12:104-6 (1983).

31. Zaltman, Innovations and Organizations, p.137.

32. Ibid., p.158-59.

33. Jerald Hage and Robert Dewar, "Elite Values Versus Organizational Structure in Predicting Innovation," Administrative Science Quarterly 18:285 (Sept. 1973).

34. Ibid., p.287.

35. Hage, Theories of Organizations, p.187.

36. Argyris, Organization and Innovation, p.193.

37. Mintzberg, Structure in Fives, p.254.

38. Ibid., p.209.

39. Ibid., p.189-93.

40. Ibid., p.213.

41. Daft, "A Dual-Core Model of Organizational Innovation," p.208.

42. Mayer N. Zald and Patricia Denton, "From Evangelism to General Service," Administrative Science Quarterly 8:234 (Sept. 1963).

43. Aiken, "The Organic Organization and Innovation," p.72.

44. Katz, "High Performance Research Teams," p.32.

45. James M. Utterback, "The Process of Technological Innovation within the Firm," Academy of Management Journal 14:75-88 (Mar. 1971).

46. Zaltman, Innovations and Organizations, p.120. 
47. Hage, Theories of Organizations, p.44.

48. Jon L. Pierce and Andre L. Debecq, "Organization Structure, Individual Attitudes and Innovation," Academy of Management Review 2:36 (Jan. 1977).

49. Mintzberg, Structure in Fives, p.256.

50. Ibid., p.268.

51. Connie R. Dunlap, "Organizational Patterns in Academic Libraries, 1876-1976," College \& Research Libraries 37:402 (Sept. 1976).

52. Victor A. Thompson, "The Organizational Dimension," Wilson Library Bulletin 42:700 (Mar. 1968).

53. Peter F. Drucker, "Managing the Public Service Institution," College \& Research Libraries 37:5 Jan. 1976).

54. Ibid., p.7.

55. Harvey F. Kolodny, "Managing in a Matrix," Business Horizons 24:23 (Mar./Apr. 1981).

56. See Sidney Forman, "Innovative Practices in College Libraries," College \& Research Libraries 29:486-92 (Nov. 1968); "1985: New Technology for Libraries," Library Journal 105:1473-78 (July 1980); Don R. Swanson, "Miracles, Microcomputer and Librarians," Library Journal 107:1055-59 (June 1982).

57. Mary Lee Bundy, "Conflict in Libraries," College \& Research Libraries 27:253-62 (July 1966).

58. Patricia Senn Brevik, "A Model for Library Management," Personnel in Libraries: LJ Special Report \#10 (New York: Bowker, n.d.), p.4-9.

59. Howard W. Dillon, "Organizing the Academic Library for Instruction," The Journal of Academic Librarianship 1:4-7 (Sept. 1975).

60. Robert F. Moran, Jr., "Improving the Organizational Design of Academic Libraries," Journal of Academic Librarianship 6:140-45 (July 1980).

61. Klaus Musmann, "The Diffusion of Innovations in Libraries," Libri 32:270 (1982).

62. Booz, Allen, and Hamilton, Inc., Organization and Staffing of the Libraries of Columbia University: A Case Study (Westport, Conn.: Redgrave Information Resources Corp., 1973).

63. Lowell Martin, Organizational Structure of Libraries (Metuchen, N.J.: Scarecrow, 1984), p.83, 203.

64. Gardner Hanks and C. James Schmidt, "An Alternative Model of a Profession for Librarians," College \& Research Libraries 36:175-87 (May 1975).

65. Jerald Hage and Michael Aiken, "Program Change and Organizational Properties; A Comparative Analysis," American Journal of Sociology 72:511 (Mar. 1967).

66. Joseph McDonald, "Organizational Structure and Effectiveness of Information Organizations," Drexel Library Quarterly 17:50 (Spring 1981).

67. Miriam A. Drake and Harold A. Olsen, "The Economics of Library Innovation," Library Trends 28:89 (Summer 1979).

68. Helen Howard, "Organization Theory and Its Application to Research in Librarianship," Library Trends 32:482 (Spring 1984).

69. Charles R. Martell, Jr., The Client-Centered Academic Library (Westport, Conn.: Greenwood, 1983), p.68.

70. Ibid., p.72.

71. Terrence E. Deal and Allan A. Kennedy, Corporate Cultures: The Rites and Rituals of Corporate Life (Reading, Mass.: Addison-Wesley, 1982), p.189.

72. Thomas J. Peters and Robert H. Waterman, Jr., In Search of Excellence: Lessons From America's Bestrun Companies (New York: Harper, 1982), p.193-98.

73. Klaus Musmann, "The Adoption of OCLC by the California State University and Colleges: A Case Study of Diffusion of a Technological Innovation in a Complex Library Organization," (Ph.D. diss., Univ. of Southern California, 1981).

74. Thomas W. Shaughnessy, "Library Administration in Support of Emerging Service Patterns," Library Trends 28:139-49 (Fall 1979).

75. A. J. Dyson, "Library Instruction in University Undergraduate Libraries," in Progress in Educating the Library User, ed. John Lubans (New York: Bowker, 1978).

76. John R. Rizzo, Management for Librarians: Fundamentals and Issues (Westport, Conn.: Greenwood, 1980), p.122.

77. Helen Arlene Howard, "The Relationship between Certain Organizational Variables and the Rate of Innovation in Selected University Libraries," (Ph.D. diss., Rutgers Univ., 1977).

78. Helen A. Howard, "Organizational Structure and Innovation in Academic Libraries," College \& Research Libraries 42:429 (Sept. 1981).

79. Clark, "The Contradictions of Change in Academic Systems," p.113.

80. Charles A. Bunge, "Strategies for Updating Knowledge of Reference Resources and Techniques," $R Q$ 21:231 (Spring 1982). 
81. Dewar, "An Examination of the Reliability and Validity," p.127.

82. Howard, "The Relationship between Certain Organizational Variables and the Rate of Innovation," p.155.

83. Maurice P. Marchant, Participative Management in Academic Libraries (Westport, Conn.: Greenwood, 1976).

84. Jane G. Flener, "Staff Participation in Management in Large University Libraries," College \& Research Libraries 34:278 (July 1973).

85. Beverly P. Lynch, "An Empirical Assessment of Perrow's Technology Construct," Administrative Science Quarterly 19:338 (1974).

86. Hay Associates, "City of San Jose Study of Management Classes (Classification of All Jobs in City Personnel Team, Training and Review),"' (City of San Jose, Calif., Personnel Department, 198?).

87. Wilson Luquire, "Attitudes Toward Automation/Innovation in Academic Libraries," Journal of Academic Librarianship 8:344-51 (Jan. 1983).

88. Joan Bechtel, "Collegial Management Breeds Success," American Libraries 12:607 (Nov. 1981).

89. Louis Kaplan, "The Literature of Participation: From Optimism to Realism," College \& Research Libraries 36:477 (Nov. 1975).

90. Louis Kaplan, "On Decision Sharing in Libraries: How Much Do We Know?" College \& Research Libraries 38:25-31 (Jan. 1977).

91. Rosemary Ruhig Du Mont, "A Conceptual Basis for Library Effectiveness," College \& Research Libraries 42:103-11 (Mar. 1980).

92. Richard M. Dougherty, "Libraries and Innovations," in Essays for Ralph Shaw, ed. Norman Stevens (Metuchen, N.J.: Scarecrow, 1975), p.34.

93. Hage, Social Change in Complex Organizations, p.103-4.

94. Carlos Cuadra, "Libraries and Technological Forces Affecting Them," ALA Bulletin 63:767 (June 1969). 